\title{
RECIPIENTES DE CULTO DE LA NECRÓPOLIS DE TOYA (PEAL DE BECERRO, JAÉN)
}

\author{
POR \\ JUAN PEREIRA SIESO \\ Universidad de Castilla-La Mancha. Toledo
}

\begin{abstract}
RESUMEN
Se estudian en este trabajo dos recipientes cerámicos procedentes de la necrópolis de Toya, una de la más significativas de la Alta Andalucía, a pesar de las carencias que presenta su documentación arqueológica. El estudio morfológico e iconográfico efectuado permite matizar algunas de las interpretaciones que se han hecho sobre estos recipientes, así como proponer su identificación como elementos de culto de una divinidad femenina e indicadores de la existencia de un sacerdocio desempeñado por mujeres 1 .
\end{abstract}

\section{SUMMARY}

We study here two ceramic vases from the Toya necropolis, which is one of the most significant of Alta Andalucía despite the lack of precise archaeological evidence. Our morphological and iconographical study allows us to shape the existing interpretations. We can also propose the identification of the objects as cult elements of a goddess and as evidence for the existence of a femenine priesthood.

En las salas que el Museo Arqueológico Nacional dedica a la cultura ibérica, se exponen algunos de los materiales cerámicos más representativos de las necrópolis ibéricas de la Alta Andalucía. En la vitrina dedicada a la necrópolis de Toya, se exhibe un singular recipiente cerámico, que hace pareja con otro; ambos han merecido en ocasiones la atención de distintos investigadores, pero nunca han sido estudiados con detalle.

Con los números 33.681 y 33.682 del catálogo general del Museo Arqueológico Nacional, estos dos recipientes, a los que nos referiremos a partir de ahora como $\mathrm{n}^{\circ} 1 \mathrm{y} \mathrm{n}^{\circ} 2$, presentan las siguientes características: son de pequeño tamaño, 11,2 y 10,1 $\mathrm{cm}$ para el cuerpo y 5,9 y $6,4 \mathrm{~cm}$ para la tapadera respectivamente. Presentan un borde ligeramente apuntado-redondeado, separado por un ligero estrangulamiento del hombro que aparece marcado por una carena de donde arrancan dos asas verticales que terminan en el sector superior del cuerpo.

Este trabajo ha sido realizado dentro del Proyecto DGCYT PB95/0375: El poblamiento ibérico en el Sureste Peninsular: una perspectiva espacial. Ministerio de Educación y Cultura.
Éste es de perfil bitroncocónico con dos sectores bien diferenciados, el superior de perfil convexo que termina en una carena donde comienza el sector inferior de tendencia ligeramente cóncava, que lleva una moldura (figs. 1 y 2). Los ejemplares tienen un pie alto, ligeramente moldurado, con el fondo hundido y umbo. La tapadera en estos ejemplares presenta un borde apuntado con un perfil convexo hasta una moldura, a partir del cual el perfil se hace ligeramente cónico para terminar en un asidero. La pasta es de color anaranjado, muy cuidada, sobre la que se aplicó un engobe rojizo-amarillento y presenta un degrasante de muy pequeño tamaño a base de caliza y mica.

La decoración de estos recipientes es de dos tipos, pintada y plástica. La primera es de color vinoso, a base de bandas paralelas distribuidas por el cuerpo que enmarcan dos zonas en el cuerpo decoradas con motivos geométricos. En el caso del ejemplar $n^{\circ} 1$ se trata de dos frisos de círculos concéntri$\cos$, mientras que en el ejemplar $\mathrm{n}^{\circ} 2$ el friso superior es de círculos concéntricos y el inferior de semicírculos concéntricos. En las tapaderas, la del ejemplar $n^{\circ} 1$ presenta ocho grupos de semicírculos concéntricos que no llegan a contactar con la base del asidero, mientras que la del ejemplar $n^{\circ} 2$ presenta un motivo decorativo más complejo, al combinar cinco grupos de círculos concéntricos en la base del citado asidero (figs. 1, 2 y 10).

La decoración plástica consiste en un cordón de superficie plana situado en el sector central del cuerpo de ambos ejemplares, decorado con un motivo estampillado de rombos excisos entre aspas en negativo, enmarcado por bandas en el ejemplar $n^{\circ} 1$ y con una banda de color vinoso sobre el estampillado en el ejemplar $n^{\circ} 2$. En las tapaderas de los ejemplares destaca una moldura estrecha decorada a base de incisiones y en el asidero un ornitomorfo modelado sin excesivos detalles anatómicos (figs. 1 y 2).

Estos recipientes, como ya se ha indicado, proceden de la necrópolis ibérica de Toya, que debe su fama a la impresionante cámara sepulcral hipogea y al variado ajuar que se rescató de su interior, así como a la colección de vasos ibéricos y áticos pro- 

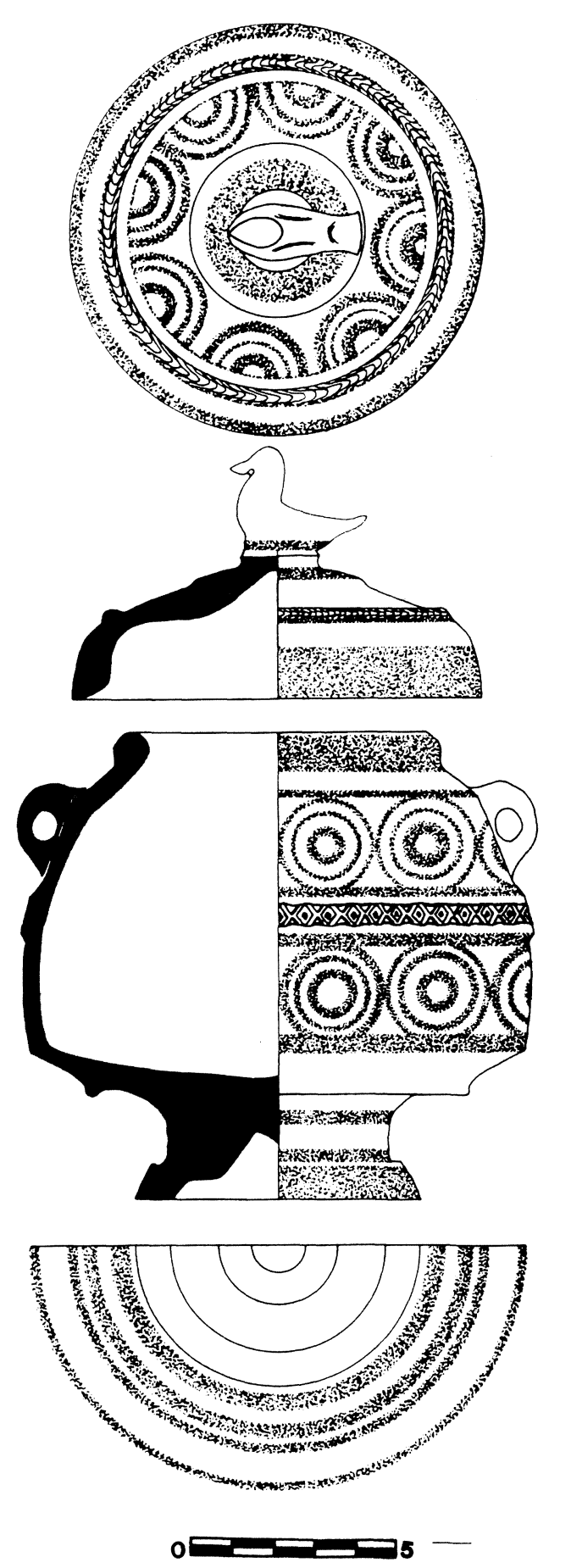

Fig. 1.-Ejemplar $\mathrm{n}^{\circ} 1$ de Toya.

cedentes de otros enterramientos de menor monumentalidad, que se encuentran dispersos por distintos museos nacionales y extranjeros, si bien la mayoría se encuentran depositados actualmente en el Museo Arqueológico Nacional.
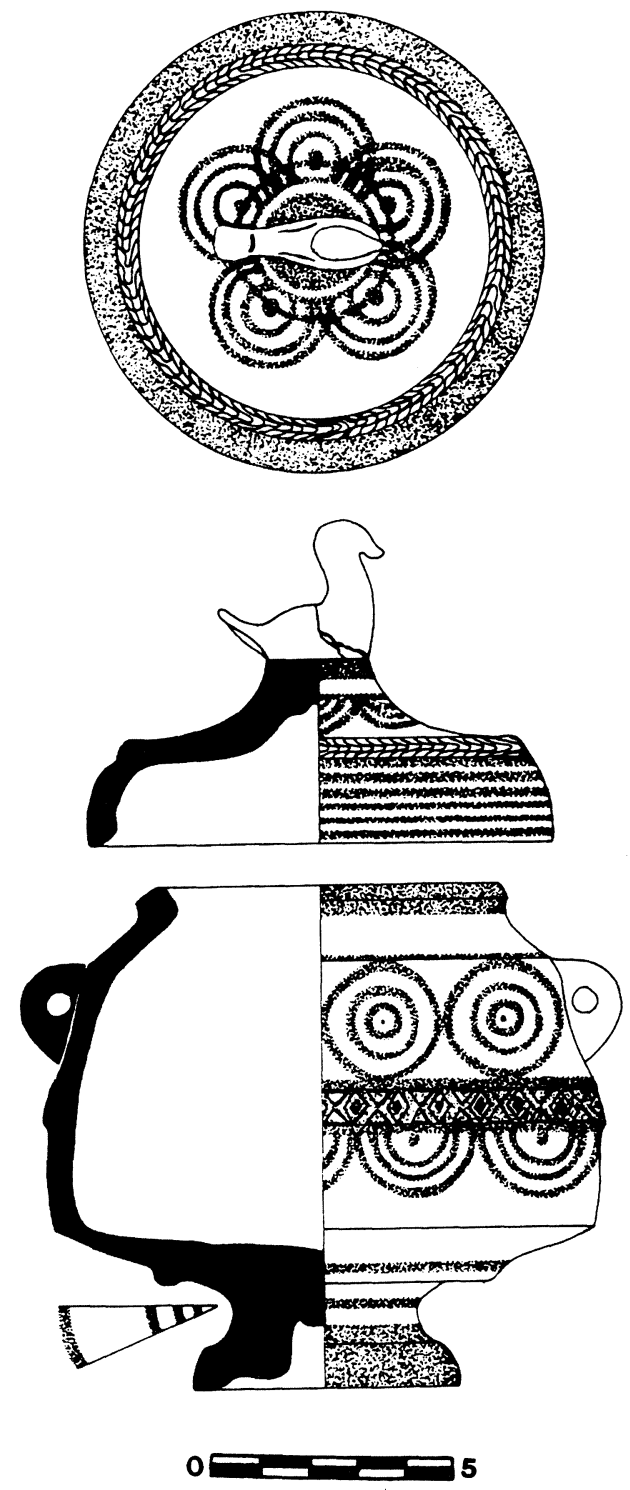

Fig. 2.-Ejemplar $\mathrm{n}^{\circ} 2$ de Toya.

Como han señalado distintos autores (Pereira, 1987; Pereira y Chapa, 1991), las circunstancias de su hallazgo casual en 1908, su posterior expolio y los planteamientos científicos de la época condicionaron que los trabajos de Cabré (1925) y Mergelina (1944) se limitasen a documentar «in situ» y en colecciones particulares parte de lo expoliado en un caso, y a restaurar la cámara efectuando algunos sondeos sin un plan concreto, en otro. Estas limitaciones se reflejan en que se desconoce el número total de sepulturas de distinto tipo que conformaban la necrópolis, la localización y descripción de las estructuras funerarias distintas de la cámara son 
muy imprecisas, el registro del ajuar es parco en detalles y la documentación gráfica es deficiente (Pereira y Chapa, 1991: 192). Sólo contamos con estudios detallados para la cámara (Cabré, 1925; Madrigal, 1997), parte del repertorio de vasos ibéricos (Pereira, 1979) y los restos de carro documentados dentro y fuera de la cámara (Fernández-Miranda y Olmos, 1986), pero para la mayoría de los materiales que proceden de esta necrópolis no se puede fijar con precisión su contexto arqueológico.

Asi pues, los dos ejemplares que nos ocupan carecen de contexto claro, si bien su estado de conservación y las escasas referencias conservadas parecen confirmar su procedencia de un contexto funerario. Sin embargo, no podemos saber si formaban parte de la misma tumba y, si se dió esta circunstancia, si pertenecían al mismo enterramiento, en qué lugar de la tumba se depositaron o con qué otros elementos estaban asociados.

La primera referencia sobre estos dos ejemplares la realiza Cabré en su trabajo sobre la cámara de Toya y los materiales «expoliados» a los que pudo acceder, entre los que cita «... dos especiales copas con un pájaro sobre su tapadera, estrías y círculos pintados de rojo» (Cabré, 1925: 97-99), reproduciendo en la tabla de formas cerámicas un boceto del ejemplar $n^{\circ} 1$. Una referencia más escueta aparece en el trabajo de Pericot (1934) sobre la España Primitiva y Romana, en la que aparece una fotografía del ejemplar $n^{\circ} 2$, sin referencia en el texto, ni número de página o de lámina.

La primera identificación de estos dos ejemplares como imitaciones de modelos áticos, más concretamente píxides, se debe a García y Bellido, quien en distintos trabajos repetirá dicha valoración reproduciendo en una ocasión los dos ejemplares (García y Bellido, 1947, 1976 y 1980: fig. 135). Similar valoración será adoptada por otros investigadores como Fernández-Chicarro (1955: 331) cuando habla del «... pixis procedente de la antigua Tugia», al buscar paralelos a la decoración pintada y plástica de un recipiente cerámico de una tumba de los Castellones de Ceal. También Blanco Freijeiro (1963: 91) los describe como «... tarros o joyeros que imitan un pyxis» y Arribas (1965: 191 lám. 16) destaca el conjunto de imitaciones de crateras y píxides griegas en la necrópolis de Toya.

Los últimos trabajos en los que se hace referencia a estos ejemplares presentan una documentación gráfica más detallada e inciden en su carácter de imitaciones, si bien se matiza que no se trata de imitaciones fidedignas de prototipos áticos, sino más bien de una reelaboración del alfarero indígena (Pereira y Sánchez, 1985: 93-94). Una línea similar
mantiene.Aranegui, que publica el ejemplar $n^{\circ} 2$, que es descrito como la versión ibérica de la caja para guardar afeites de la vajilla ática, aunque identifica el prototipo como una lécane si bien lo cita por error como procedente de Baza (Aranegui, 1992). El equipo del yacimiento de Garvâo, en la revisión que hacen de los vasos con decoración ornitomorfa, identifican las piezas de Toya como píxides y las valoran como el atributo de una deidad femenina, a la que se dedican este tipo de recipientes, que suelen aparecer en contextos votivos (Beirâo et alii, 1985: 115-118).

Hasta el momento son los trabajos de Olmos los que no sólo han abordado el estudio de estos recipientes con mayor profundidad, sino también los que han abierto nuevas perspectivas en el estudio de las imitaciones ibéricas de formas áticas en general. Este investigador, quien adopta la nomenclatura de píxide para los ejemplares que presentamos, matiza que su estructura de caja con pie y tapadera con asa en forma de ave tiene paralelos en el mundo etrusco e itálico (Olmos, 1985). Olmos propone como paralelo indirecto los lebetes gamikoi de Beocia, decorados con palmetas y pájaros. Estos vasos están vinculados en el mundo griego al ritual de boda (Olmos, 1989: 108), lo que le lleva a plantearse cuál sería la interpretación que de estos recipientes hizo la sociedad ibérica de la Alta Andalucía. Sugiere la necesidad de profundizar en el estudio simbólico y funcional de estas píxides, probablemente vinculadas al culto de una divinidad femenina, cuyos símbolos serían los círculos y las palomas proponiendo como paralelo más claro el recipiente de borde y tapadera dentada de Alcoy (Olmos, 1989).

En trabajos posteriores, Olmos mantiene que las asociaciones de motivos decorativos circulares con un ave constituyen una unidad simbólica de tipo floral (Olmos, 1991: 217). Este tipo de símbolo asociado a la fecundidad reforzaría la funcionalidad ritual del recipiente como contenedor de plantas aromáticas. Este recipiente pertenecería al ámbito femenino, tanto por la divinidad a la que se ofrecen las plantas aromáticas, como por el personaje que realiza la ofrenda que posee y quizás encarga estos recipientes, que constituyen una forma peculiar en el repertorio cerámico de la Alta Andalucía (Olmos, 1992: 119).

Como se puede comprobar, la mayoría de las referencias sobre esta pareja de recipientes aboga por clasificarlos como una imitación de prototipos áticos, en particular la píxide. Sin embargo, un examen atento muestra que, a pesar de las semejanzas en el plano morfológico con su posible prototipo, existen 


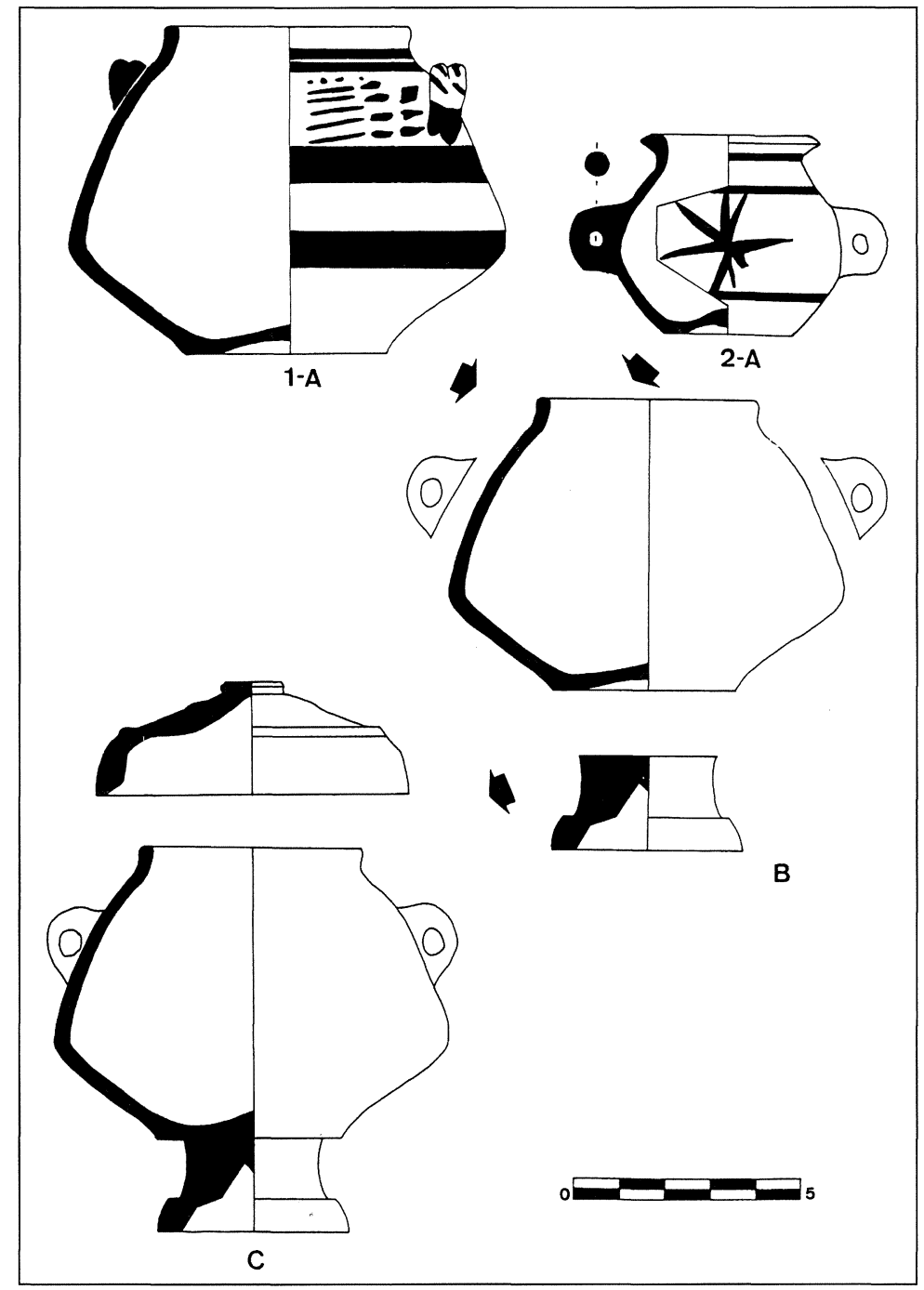

Fig. 3.-Composición morfológica a partir de ejemplares procedentes de Céal y Alhonoz.

diferencias significativas. Esta circunstancia no se puede achacar a la impericia de los alfareros ibéricos, que en el propio yacimiento de Toya han dado suficientes muestras de su capacidad para imitar formas y proporciones de los vasos áticos (Pereira y Sánchez, 1985). También creo que permite orientar el análisis de su morfología y decoración hacia las producciones cerámicas ibéricas.

En cuanto a la morfología no conocemos precedentes ni paralelos exactos en los repertorios del mundo ibérico para estos recipientes. Pero, si los consideramos como el resultado de una reelaboración de elementos y perfiles de formas documentadas en la Alta Andalucía, se pueden señalar algunos posibles prototipos. Estos se centrarían en ejemplares que tienen en común con los estudiados sus pe- queñas dimensiones y el mismo tipo de perfil bitroncocónico y que conforman el Tipo 13-A de mi propuesta tipológica, que aparecen en necrópolis de la Alta Andalucía (Pereira, 1977: fig. 247 y 1988). De entre estos ejemplares destaca el reproducido en la figura 3 (1-A) procedente de la necrópolis de Castellones de Céal (Chapa, Pereira, Madrigal y Mayoral, 1998: fig. $13 n^{\circ}$ 5) que mantendrá una estrecha vinculación no sólo en las producciones alfareras, sino también en aspectos económicos, sociales y políticos con el área de Toya (Pereira, 1987). La utilización de asas verticales de pequeño tamaño (fig. 3 2-A) tiene sus paralelos en el conjunto de vasitos con asas horizontales y verticales del depósito de Alhonoz (López Palomo, 1979 y 1981; Beirâo et alii, 1985: 118).

La adopción de un pie alto más o menos moldurado (fig. 3-B) está relacionada con la masiva entrada de productos áticos en la Alta Andalucía durante el siglo Iv a.d.C. y se documenta tanto en las imitaciones de crateras áticas y sus derivados crateriformes, como en los recipientes de perfil bitroncocónico, los de cuello acampanado o caliciforme y los llamados « tinteros» que conforman el Tipo 13-A que antes he citado. Parece por lo tanto admisible que elementos formales característicos de las producciones cerámicas del mundo ibérico del Valle del Guadalquivir fueron utilizados en la elaboración de los recipientes objeto de este estudio, de los que sólo la tapadera (fig. 3-C) supondría una cierta novedad en el repertorio de las piezas conocidas en la Alta Andalucía (Pereira, 1988: 166).

En el apartado de la decoración, destacan en primer lugar motivos pintados a base de bandas horizontales y paralelas de distintas anchuras, localizadas en la tapadera pie y cuerpo. En este último delimitan dos zonas en las que aparecen círculos concéntricos en el ejemplar $\mathrm{n}^{\circ} 1$ y asociados a semicírculos concéntricos en el ejemplar $n^{\circ} 2$. En las tapaderas el motivo principal está formado por distintas combinaciones de semicírculos concéntricos. 
La utilización de círculos concéntricos como motivo decorativo pintado está documentada en la Andalucía Occidental y en los enclaves coloniales de la costa desde el siglo vir al vi a.d.C. A partir de este mismo siglo también aparece en la Alta Andalucía donde va a perdurar hasta el siglo I d. C. Se trata de un motivo que aparece en porcentajes cercanos al $50 \%$ en las formas que configuran las recientes tipologías sobre las cerámicas a torno pintadas en Andalucía (Escacena, 1986; Pereira, 1987). En porcentajes mayores se documenta la utilización de semicírculos concéntricos, que aparecen en la Andalucía Occidental a mediados del siglo vir a.d.C. Este motivo se va a convertir en una decoración muy apreciada durante toda la segunda Edad del Hierro, según Escacena por el arraigo que en la tradición indígena tenían las decoraciones de guirnaldas a partir de líneas horizontales, como es el caso de algunas decoraciones de boquique (Escacena, 1986: 960). Se puede comprobar que en las dos áreas andaluzas, Bajo Guadalquivir y área granadina, donde primero aparecen los semicírculos concéntricos pintados como decoración de vasos a torno es donde la cerámica del complejo Cogotas I con decoración de boquique está perfectamente documentada durante el Bronce Final.

Olmos (1992) ha señalado que en los conjuntos cerámicos ibéricos de Andalucía y el Sureste el alfarero construye un lenguaje iconográfico a partir de signos geométricos sencillos, como los círculos, semicírculos y cuartos de círculos concéntricos. Las combinaciones de estos motivos se pueden interpretar como distintas versiones de una flor, reforzando la simbología de algunos vasos cuyo perfil recuerda el cáliz de una flor. El motivo geométrico se convierte en vegetal, que a su vez se puede combinar con otros motivos geométricos como en el cálato de La Serreta, en el que un ave picotea unos círculos unidos a un tallo (Pericot, 1979: 142; Olmos et alii, 1992: 94); motivo de inspiración oriental del pájaro que se alimenta del árbol de la vida. En las tapaderas de los ejemplares de Toya, la combinación de los semicírculos reproduce la visión en planta de una flor abriéndose, con un diseño similar al que aparece en un plato de La Serreta (Pericot, 1979: 133; Olmos et alii, 1992: 94) que, en el caso de Toya, se ve rematado por el asidero de la tapadera en forma de ave que parece surgir del centro de la flor. La asociación de aves y círculos/flores, es el símbolo de una divinidad femenina entre cuyas atribuciones destacaría con todas sus implicaciones la fecundidad, y en cuyo culto se efectuaban rituales de libación o de combustión de plantas aromáticas.

Por lo que se refiere a los motivos decorativos plásticos, los ejemplares de Toya presentan tres tipos diferentes. El primero es un cordón plano localizado en el sector central del cuerpo y sobre el que aparece un motivo de rombos excisos entre aspas en negativo. El único paralelo que se puede proponer procede de la cercana necrópolis de Castellones de Céal. En una de las tumbas excavadas en las primeras campañas (Fernández-Chicarro, 1956: 108-109) se documentó un crateriforme con este tipo de decoración plástica (fig. 4,1) junto con otros motivos pintados entre los que destacan dos frisos de pequeños círculos concéntricos, semejantes a los anteriormente reseñados. La cronología de esta tumba se fija en el segundo cuarto del siglo IV a.d.C. (Sánchez, 1991: 530) a partir de una cratera de campana de figuras rojas atribuída al pintor del Tirso Negro, que fue utilizada como urna cineraria (Chapa, Pereira, Madrigal y Mayoral, 1998: fig. 13,3). También formaba parte del ajuar de esta tumba el prototipo formal que antes se ha reseñado (fig. 3, 1-A).

El segundo motivo decorativo plástico, una moldura sobre la que se realizaron una serie de incisiones, se localiza sobre el hombro de las tapaderas. También en este caso sólo se cuenta con una decoración semejante en una pieza cerámica procedente de Cástulo, de la necrópolis de Baños de la Muela (fig. 4,2) donde se fecha en torno a la segunda mitad del siglo IV a.d.C. (Pereira, 1988: 155).

El tercer motivo decorativo plástico consiste en un ornitomorfo modelado sin excesivos detalles, situado en el remate superior de las tapaderas cumpliendo la función de asidero. Este tipo de motivo en bulto redondo es relativamente frecuente en el área ibérica siendo su paralelo más directo el asidero de una cajita/vaso de borde dentado de La Serreta en Alcoy (fig. 5,8; Page del Pozo, 1984: 103). De este yacimiento también procede una placa de arcilla en la que aparece una diosa entronizada que amamanta a dos niños con un ave posada a su izquierda (fig. 5,1), acompañada o visitada por mujeres y niños que tocan unas flautas dobles (Tarradell, 1968: 64; Llobregat, 1972: fig. XV) lo que lleva a considerar su pertenencia a un lugar de culto, como el integrado por los departamentos 12 y 13 de Liria donde se ha documentado una paloma de terracota (Bonet, 1995: fig. 33; Bonet y Mata, 1997: fig. 4). Hallazgos semejantes de ornitomorfos asociados a sistemas de cierre o tapaderas en cerámica han aparecido en Coimbra del Barranco Ancho (fig. 5,6; Page del Pozo, 1984: 103; García Cano, 1997: 185 fig. 150) y Carmona (Cardenete et alii, 1989: 573), a los que hay que añadir el que aparece catalogado en la colección Durán, del que sólo se indica su procedencia del Sureste Peninsular (Conde, 1992: 118). 


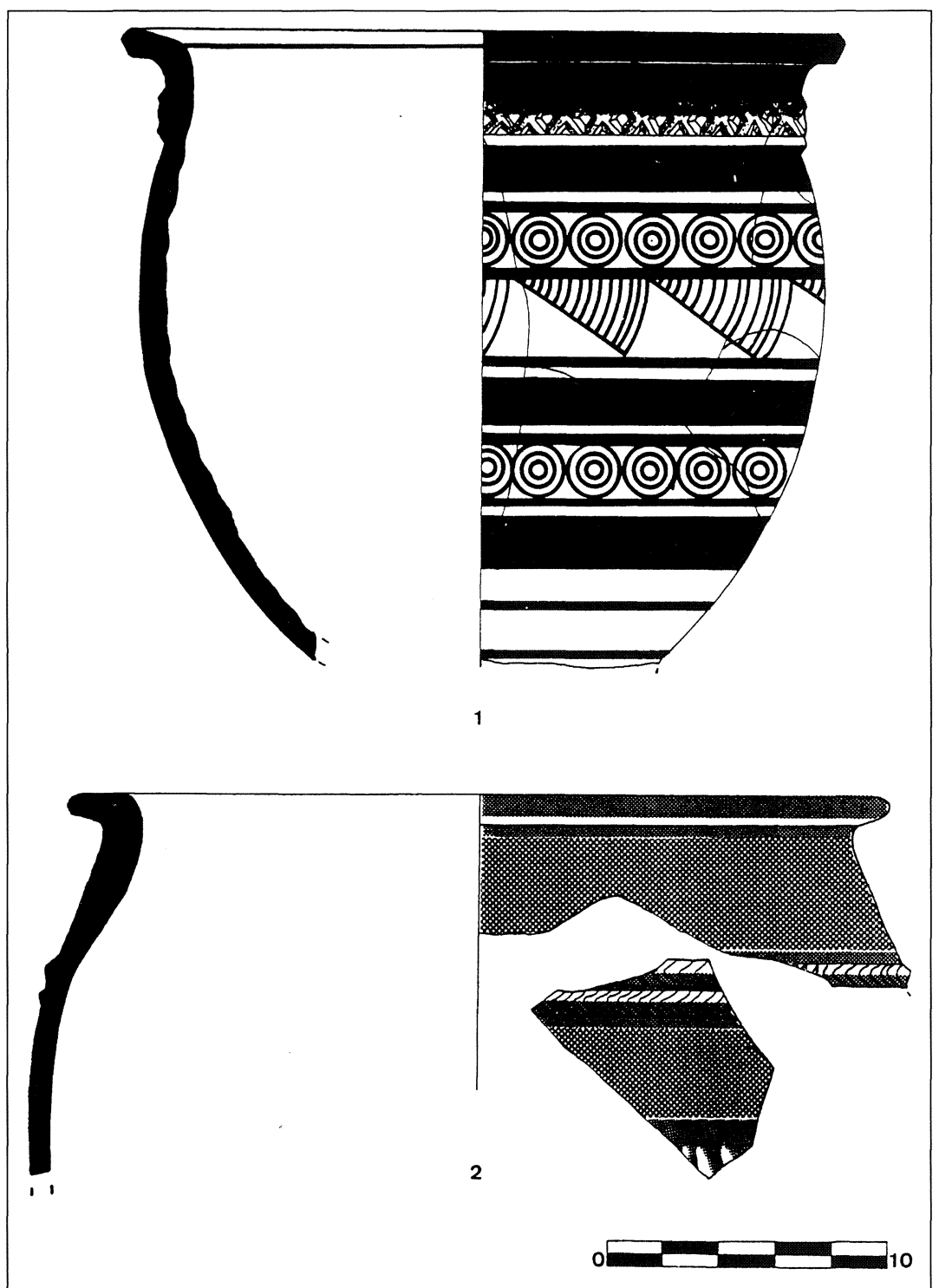

Fig. 4.- $\mathrm{N}^{\circ} 1$ Céal. No 2 Baños de la Muela (Cástulo).

del que existen innumerables versiones en el mundo mediterráneo, el alfarero indígena pudo crear una nueva forma cerámica realizando una síntesis o reelaboración de elementos morfológicos y decorativos de indudable procedencia autóctona tal como se presenta en la figura 6. La cronología de la segunda mitad del siglo IV a.d.C. que se puede atribuir a la casi totalidad de los elementos tipológicos reseñados $\mathrm{y}$ que coincide con el momento de mayor productividad, variedad y expansión de los alfares de la Alta Andalucía, no hacen sino corroborar esta hipótesis (Pereira, 1989).

Queda sin embargo por desentrañar la cuestión de la funcionalidad de estos recipientes. No habiendo dudas sobre el contexto funerario de ambos, sin embargo surgen todo tipo de interrogantes ya reseñadas y que son de difícil respuesta. Pese a todo se puede aventurar que la función desempeñada en sus respectivos enterramientos era la de elemento de ajuar relacionado con aspectos significativos de la vida privada o pública de su

También se han documentado ornitomorfos como elementos decorativos de distintos tipos de recipientes en Alhonoz (fig. 5,7 y 11) y Garvâo (Beirâo et alii, 1985: 115), en contextos que se interpretan como depósitos de ofrendas de carácter cultual. También como elementos complementarios de las representaciones femeninas en terracota del Puig de Molins, donde son frecuentes las imágenes de muchachas sosteniendo palomas como oferentes o iniciadas al servicio de la diosa Tanit (Almagro Gorbea, M.J., 1980: 88-89).

Como conclusión se puede proponer que, si bien existe una cierta influencia foránea en la idea de la fabricación de un recipiente pequeño con tapadera, propietario o propietaria. Una vez más el análisis de los elementos tipológicos nos puede servir de orientación.

Los precedentes del uso de pequeños ornitomorfos como elementos decorativos en la cultura ibérica se pueden rastrear en la toréutica y la orfebrería del periodo orientalizante, siendo uno de los ejemplares más significativos las arracadas del tesoro de la Aliseda. En estos pendientes aparecen parejas de aves que parecen libar de una flor, reproduciendo el tema oriental del árbol de la vida, símbolo de la fecundidad de la naturaleza (Olmos, 1992: 86). También se utilizan ornitomorfos en el bocado de caballo denominado Bronce Carriazo (Olmos, 1992: 69) 
que presenta una imagen de la diosa Hathor entre dos prótomos de aves acuáticas que forman una barca solar (Blázquez, 1975: 102-105). Este símbolo, conformado por aves migratorias cuya presencia son la referencia de los cambios estacionales, según algunos autores se difundirá desde el área mediterránea y a través de la Meseta al Noroeste Peninsular, donde será asociado con otros símbolos solares (Pérez, 1980). A esta fase orientalizante pertenece el de asador de bronce adquirido por el Museo de Sevilla (Fernández, 1993: 467-80), cuyo mango ha sido transformado en una figurilla femenina bifronte que con las manos alzadas presenta dos pájaros. Esta decoración ornitomorfa también aparece en la empuñadura del asador de Alvaicere (Almagro Gorbea, M., 1974: 356). Por último, destacar el fragmento de diadema de oro procedente de Crevillente (González Prats, 1978: 354) decorada con una serie de motivos repujados como palmetas, aspas y aves dispuestas en línea. Este motivo aparece en el caldero de plata de la tumba Bernardini de Palestrina (Pallottino, 1955: fig. 29) con una cronología de finales del siglo

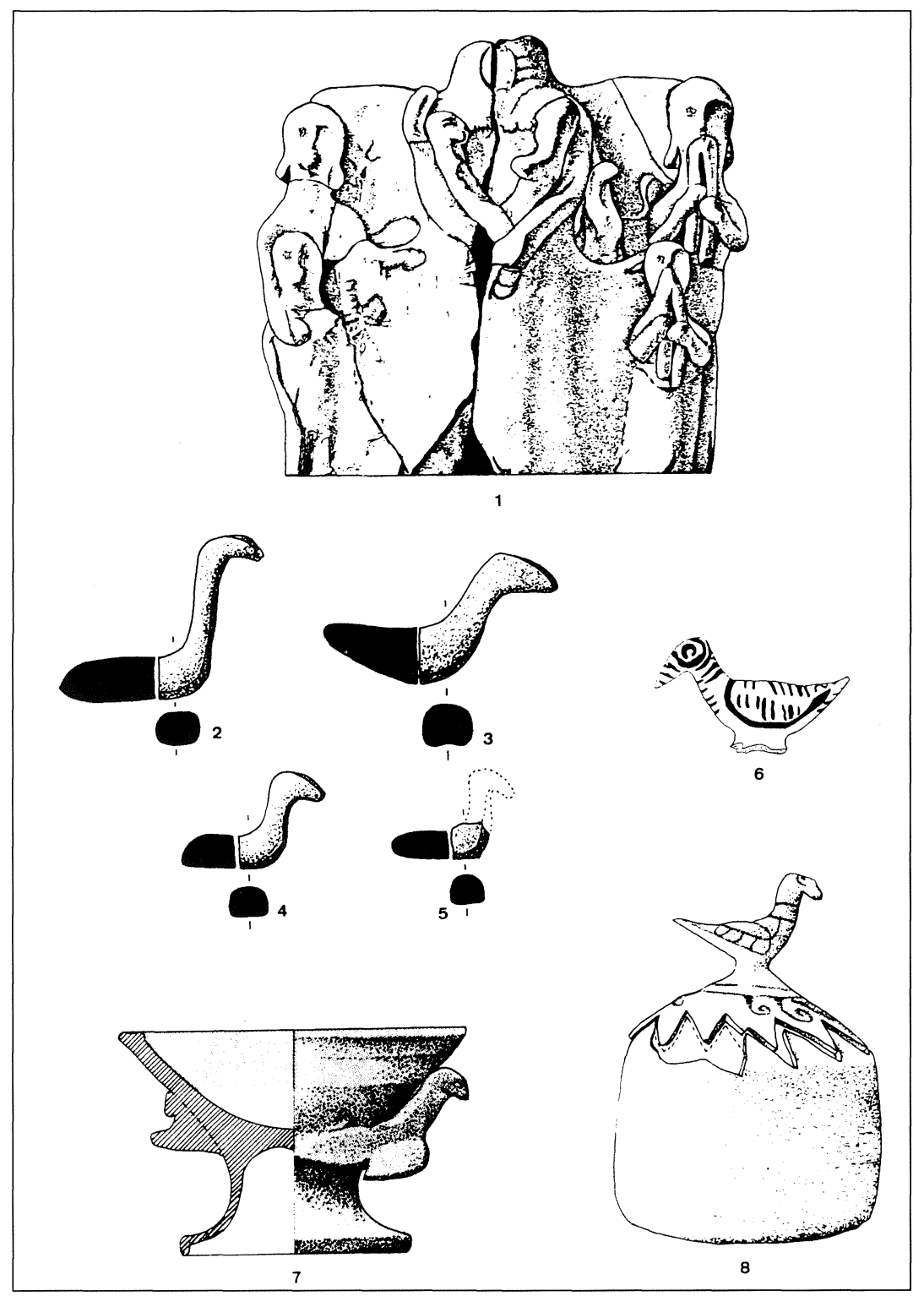

Fig. 5.- $\mathrm{N}^{\circ} 1$ Alcoy (según Blázquez), 2 a 5 Clares (Guadalajara), 6 Coimbra del Barranco Ancho (según García Cano), 7 Alhonoz (según López Palomo), 8 Alcoy. Distintas escalas.

vi a.d.C. similar a la que podemos atribuir a las placas del tesorillo orientalizante de La Serradilla en las que aparece un motivo repujado de dos aves afrontadas (Almagro Gorbea, M., 1977: 224-5).

En un momento posterior podemos encuadrar los ornitomorfos metálicos documentados en los complejos monumentales extremeños de El Turuñuelo (Jiménez y Domínguez de la Concha, 1995: 142) y Cancho Roano, en el que destacan las «palomas» que lleva en los brazos el despotes Theron que aparece en las placas de los bocados de caballo (fig. 7,7; Maluquer, 1983: 55). Un conjunto interesante de ornitomorfos está formado por una serie de colgantes de bronce (fig. 7,3,4 y 6) que aparecen en una serie de yacimientos en torno a la desembocadura del Ebro y en el llano castellonense septentrional como las necrópolis de Mianes (Tarragona) y el Bovalar (Castellón) y la Tore de Foios (Castellón; Rafel, 1997: 103-110). Valorados como elementos de adorno del vestido de adscripción femenina (Maluquer, 1987: 16) y con una cronología entre finales del siglo vi y principios del v a.d.C., la utilización de los ornitomorfos se considera como un elemento de amplia difusión tanto en el mundo mediterráneo 


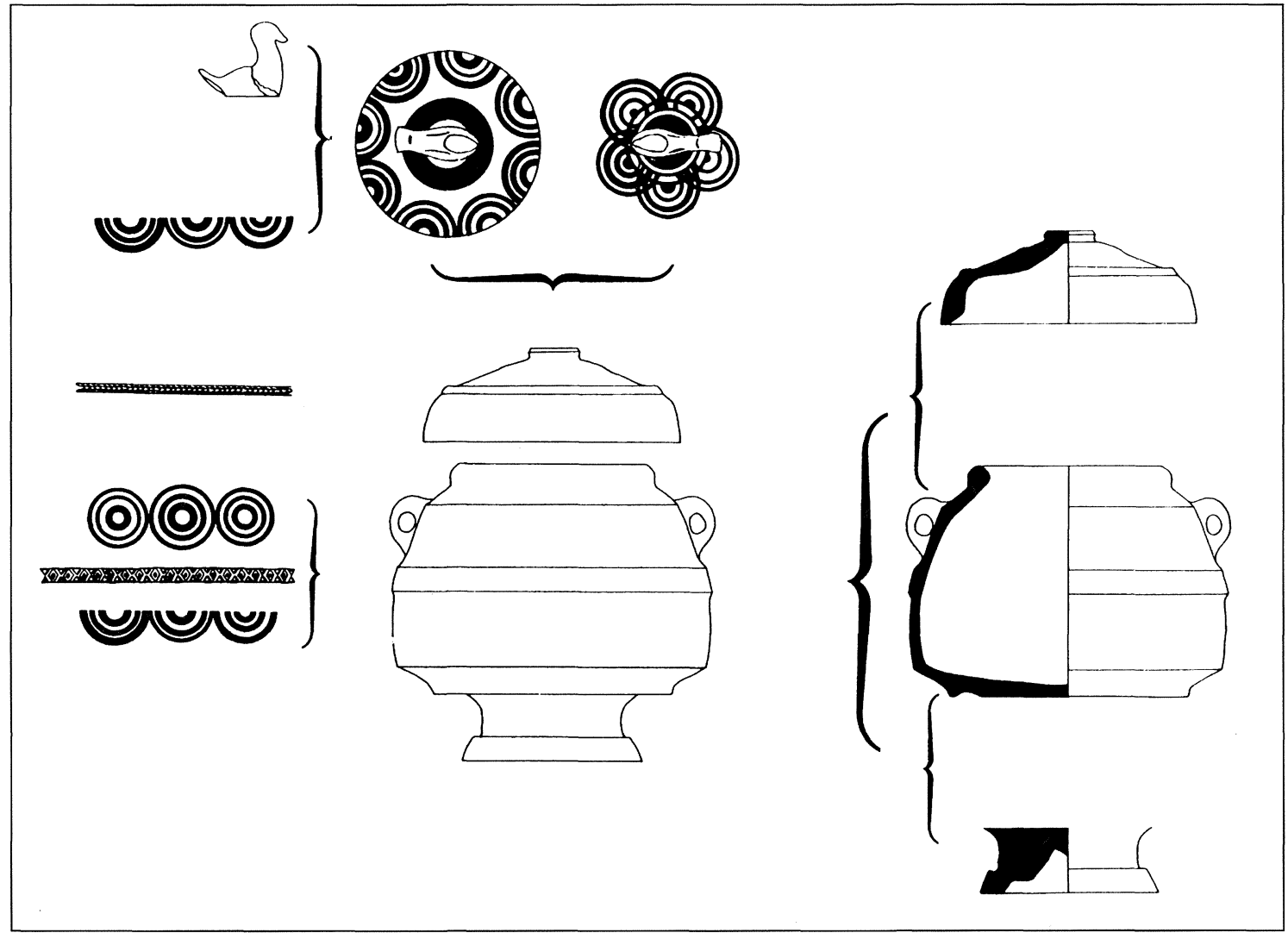

Fig. 6.-Síntesis morfológica e iconográfica de los recipientes de Toya. Distintas escalas.

como en el continental. En un marco más general, frente a quienes los adscriben a una tradición centromediterránea anterior al período colonial, haciendo responsable de su reactivación posterior tanto al intermediario fenicio como al elemento indígena (Rafel, 1997: 112), existe otra propuesta que señala una gran influencia del norte de Italia y el área del Adriático, sobre todo del área balcánica (Neumaier, 1996: 259).

Otro ornitomorfo, asociado en este caso a un objeto de culto, aparece en la mano de la joven desnuda que sirve de pie al timiaterio de bronce del poblado ibérico de la Quéjola (Albacete). Llama la atención en la figura femenina la posición frontal, adelantando ligeramente la pierna izquierda para expresar el movimiento mientras sostiene en la mano un ave, en una actitud similar a la que presentan las cariátides que sirven de mango de espejo en el mundo griego, cuya cronología oscila entre los siglos vi y v a.d.C. (Congdom, 1981: plate 38-90). La pieza de la Quéjola, si bien procede de un taller orientalizante del área andaluza (Olmos y Fernández-Miranda, 1987), apareció en el interior de un edificio de uso especial dentro del poblado, donde se encontraron pondera, armas, copas Cástulo sin usar y el propio timiaterio (Blánquez, 1995: 198).

De época claramente ibérica y en el apartado de las piezas metálicas hay que señalar la divinidad femenina portadora de palomas, realizada en oro, de Santiago de la Espada (Jaén; Santa Olalla, 1946: 139) que es valorada como el resultado de influencias de tipo estrusco (Blázquez, 1955-56: 121) y el pinjante de bronce rematado por un ave (figura 7,5), que, procedente de Castellones de Céal, se conserva en el Museo de Jaén (Chapa, Pereira, Madrigal y Mayoral, 1998: fig. 27,10). Aparecen también ornitomorfos en los exvotos procedentes del Collado de los Jardines (fig. 7,1 y 2) que representan a personajes femeninos que llevan en sus manos como ofrendas un ave (Prados, 1992: 144-216), uno de los cuales presenta el mismo gesto de alzar dos aves como en el asador de bronce antes reseñado y un curioso ejemplar que representa un pie humano coronado por un ave y que es interpretado como un exvoto de un rito de paso (Prados, 1996: 279).

En el apartado de la escultura, es en el mundo griego donde aparecen los ornitomorfos como elementos iconográficos vinculados a mujeres que en 
distintas actitudes son interpretadas habitualmente como portadoras de ofrendas (Boardman, 1978: 93, 110 y 251). En el mundo ibérico peninsular cabe senalar los ejemplares en piedra procedentes de las necrópolis de El Cigarralejo y Baza. En el primer caso se trata de un fragmento de busto, en el que una mano sujeta una paloma, que apareció sobre la tumba $\mathrm{n}^{\circ} 217$ (Cuadrado, 1987: 586; Blázquez, 1957). Una iconografía muy similar presenta la Dama de Baza, que en su mano izquierda aprisiona un ¿pichón? pintado de azul del que se ha representado con cierto realismo un ala, el buche y un ojo (Presedo, 1973: 188).

En cuanto a los productos cerámicos, en el mundo griego encontramos pequeñas figuritas cerámicas de aves identificadas según los autores con palomas asociadas con el culto a Afrodita, aunque pueden aparecer también en santuarios vinculados a Demeter y Perséfone (Sánchez y Cabrera, 1998) o a divinidades menores (Amandry, 1991: 255). Función similar como elementos votivos debieron desempeñar en los santuarios púnicos, como el de
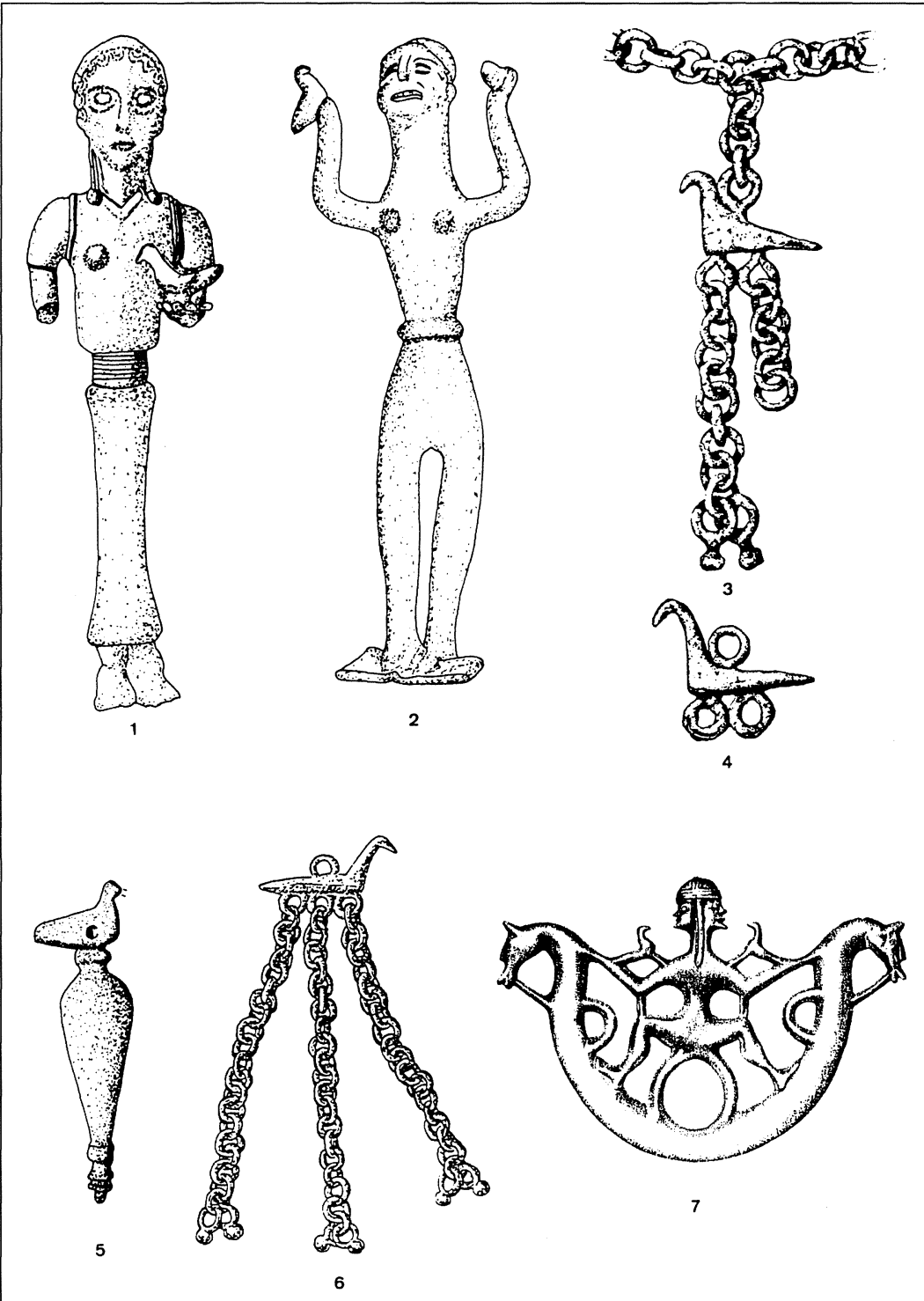

Fig. 7.- $\mathrm{N}^{\text {os }} 1$ y 2 Collado de los Jardines. 3 y 4 Mianes (según Maluquer de Motes). 5 Céal. 6 Bovalar (según Rafel). 7 Cancho Roano (según Maluquer de Motes). Distintas escalas.
Tharros, donde se han documentado una serie de ornitomorfos que, con una cronología a caballo de los siglos vi a v a.d.C. y a pesar de su estado fragmentario, presentan una gran semejanza con los ejemplares de Toya (Uberti, 1975: 24-25).

En la Península Ibérica, y completando el mapa de dispersión de los ornitomorfos citados anteriormente (fig. 8), cabría destacar la variada tipología de representaciones de ornitomorfos en cerámica. Sin embargo, para los objetivos de este trabajo sólo nos centraremos en los que podríamos agrupar bajo el denominador común de pequeños elementos decorativos de bulto redondo. Entre estos últimos más directamente relacionados con la decoración de los recipientes de Toya, habría que incluir los hallazgos en contextos funerarios, como los procedentes de las necrópolis ampuritanas fechados entre los siglos VI-IV a.d.C. (Santos, 1998: 298) y que también pueden ser interpretados como un símbolo del alma del difunto (Presedo, 1973: 197; Blázquez, 1983: 269). Distinta funcionalidad parece que tuvieron los ejemplares procedentes de la tumba 134 de Galera (Cabré y Motos, 1920: 51). Descritos como figuritas de cisne de barro gris, Cabré señala su posible pertenencia a un collar con paralelos muy directos en un ejemplar documentado en una singular tumba feme- 


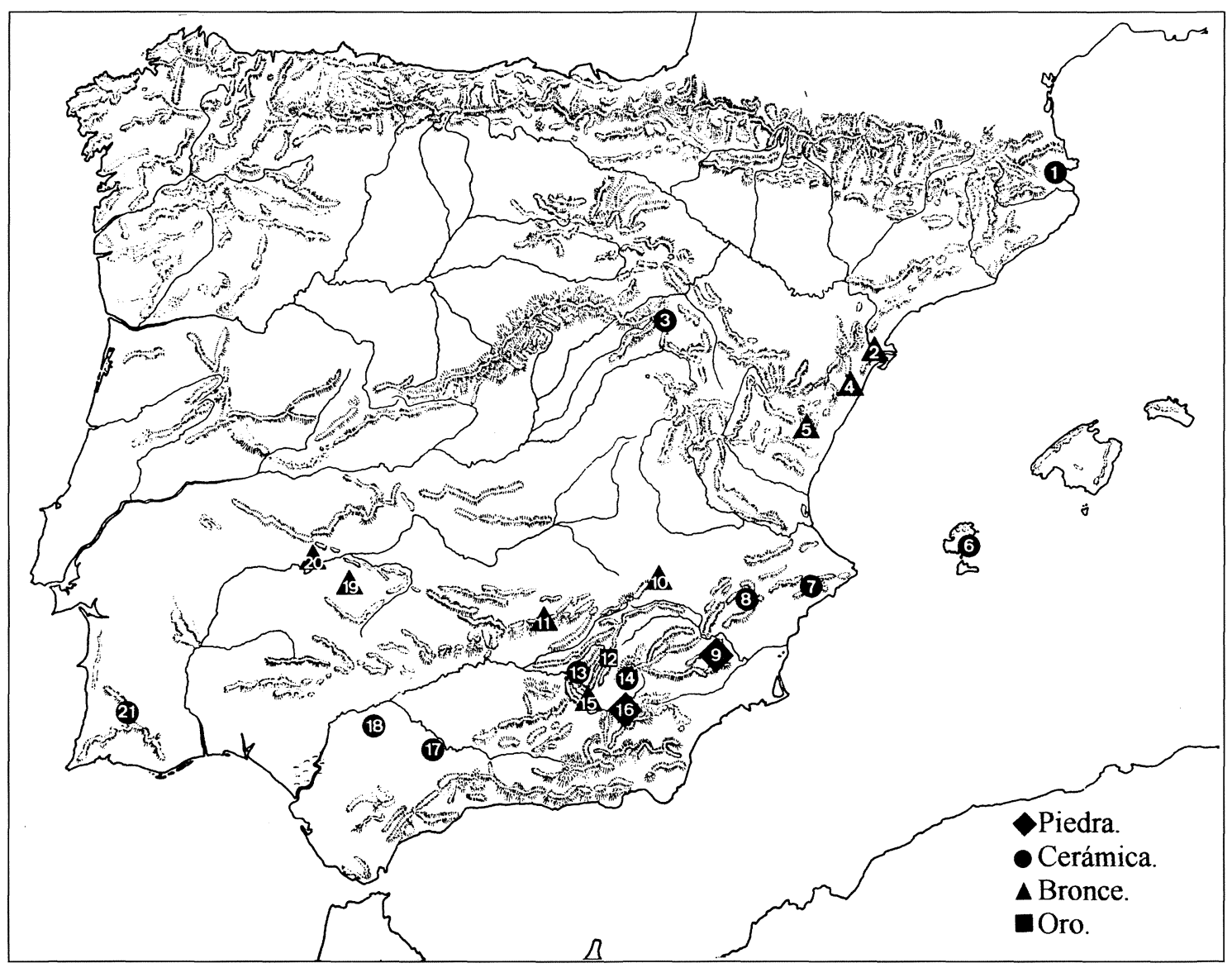

Fig. 8.-Yacimientos mencionados en el texto: 1 Ampurias, 2 Mianes, 3 Clares, 4 Bovalar, 5 Foios, 6 Puig des Molins, 7 Alcoy, 8 Coimbra del Barranco Ancho, 9 Cigarralejo, 10 Quéjola, 11 Collado de los Jardines, 12 Santiago de la Espada, 13 Toya, 14 Galera, 15 Ceal, 16 Baza, 17 Alhonoz, 18 Carmona, 19 Cancho Roano, 20 Turuñuelo, 21 Garvâo.

nina (fig. 5,2-5) de la necrópolis celtibérica de Navafría (Clares, Guadalajara) y que es interpretado como el atributo de una sacerdotisa de un culto de inspiración solar (Malpesa, 1993).

Vemos cómo, desde el período orientalizante y enmarcada en una koiné mediterránea, la utilización de ornitomorfos como elementos decorativos se documenta en la vida cotidiana del mundo femenino en los objetos de adorno personal como las agujas de hueso complemento del peinado documentadas en Coimbra del Barranco Ancho (Iniesta, Page y García, 1987: fig. 15), Cigarralejo (Cuadrado, 1987: figs. 88, 170), Covalta (Raga, 1994) y Liria (Bonet, 1995: fig. 49). En el ámbito religioso aparecen usados con profusión en las representaciones tanto de fieles como de deidades que, según la procedencia y elementos complementarios, se pueden identificar como Hathor, Astarté Demeter, Tanit, Ártemis o Afrodita. La iconografía de las divinidades femeninas experimentó durante el siglo IV a.d.C. y siguien- tes una revitalización en el Mediterráneo Occidental, que se manifiesta no sólo en la abundancia de representaciones figurativas de la divinidad, sino en la abundancia de elementos simbólicos asociados, como frutos, flores, soles y aves. Son divinidades protectoras de la fecundidad humana, animal y vegetal y, en ocasiones, diosas nutricias en cuyo culto se queman sustancias aromáticas y se ofrecen aceites perfumados, de las que se celebra su epifanía y a las que se solicita protección en las fases críticas del ciclo vital o de cambio de status social: nacimiento, matrimonio, procreación o muerte (Prados, 1996: 140; Griñó, 1992: 204-205).

Desde el punto de vista iconográfico, los motivos geométricos pintados y el asidero ornitomorfo de los recipientes de Toya se combinan para dar una lectura simbólica de amplia difusión en el Mediterráneo Occidental, adscrita a deidades de las características de Ártemis, Afrodita y Tanit y en cuyo culto cobra protagonismo el mundo femenino. 


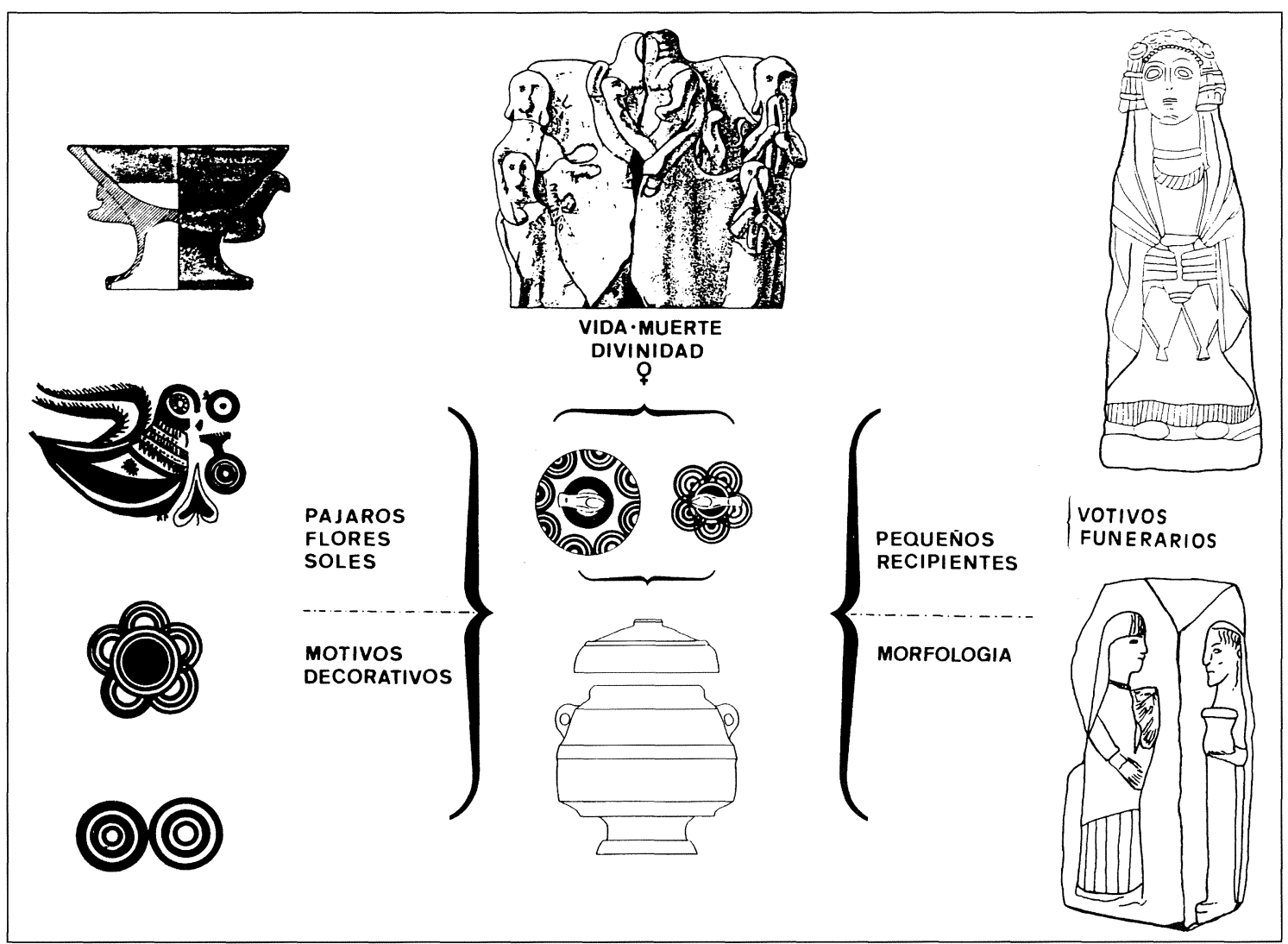

Fig. 9.- Interpretación funcional de los ejemplares de Toya como recipientes de culto de una divinidad femenina a partir del análisis morfológico y decorativo.

En lo que se refiere a su morfología, el tamaño de los recipientes de Toya ha sido uno de los argumentos manejado por algunos autores para identificarlos como elementos del ajuar personal y más concretamente como joyeros. Sin embargo, la revisión del papel de las joyas en la sociedad ibérica muestra su escasa presencia en contextos funerarios. La parquedad de los hallazgos se corresponde con la de elementos que adornaban al difunto en el momento de la cremación, mientras que la casi totalidad de las joyas que integraban el patrimonio familiar, del que son claro exponente los ejemplares más conocidos de la estatuaria ibérica, pasarían como herencia a sus descendientes (Chapa y Pereira, 1991: 33) junto con los recipientes destinados a su custodia y conservación. Esta circunstancia justifica que la interpretación de estas piezas de indudable contexto funerario como joyeros tenga escasa fiabilidad.

La utilización de recipientes singulares de pequeño tamaño, vinculados al plano íntimo o personal de individuos en su gran mayoría femeninos, lo tenemos documentado en distintos ejemplares de la escultura ibérica en el contexto de ciertos santua- rios, caso del Cerro de los Santos, y en estructuras funerarias como los relieves del monumento funerario de Osuna (Olmos, 1992: 107-133). A partir de estas representaciones, como de otras documentadas en el área ibérica, se puede concluir que la mujer ibérica de cierto status podía participar en las ceremonias de tipo religioso como oficiante, orante $\mathrm{u}$ oferente. En el caso de las orantes u oferentes, los vasos que portan, generalmente de pequeño tamaño, quedaban depositados en el espacio sagrado del santuario. Para el área andaluza resulta significativo el caso del depósito de Alhonoz, que se interpreta en la actualidad como un santuario urbano, en el que destaca el gran número de vasos cerámicos de pequeño tamaño como los de perfil caliciforme y la copa decorada en el pie con ornitomorfos que se ha reseñado anteriormente (López Palomo, 1979 y 1981). Sin embargo, es perfectamente factible que la oficiante o sacerdotisa utilice una y otra vez una serie de ornamentos y recipientes alguno de los cuales fuese de su propiedad, como sería el caso de los ejemplares de Toya para los que Olmos (1992: 119) sugiere la función de recipiente de plantas o esen- 
cias aromáticas habituales en las ceremonias de las religiones mediterráneas.

Así pues, desde el punto de vista morfológico las piezas de Toya, por su pequeño tamaño sugieren su adscripción al círculo íntimo de su propietaria, tanto en el plano de la vida cotidiana como en el de sus prácticas religiosas. Es este último plano el que podría tener más peso a la hora de identificar su posible funcionalidad, ya que la lectura de sus motivos decorativos no hace sino reforzar, por acumulación de símbolos asociados a una divinidad femenina, la identificación funcional de estos recipientes en el marco de las ceremonias que se dedican a dicha divinidad. Dicho de otro modo, en los ejemplares de Toya la decoración de los mismos refuerza su vinculación con el culto a una divinidad femenina, mientras que su tamaño y morfología los vinculan con el plano íntimo y personal de su propietaria (fig. 9).

Son conocidas las distintas propuestas que, en el marco de la Arqueología de la Muerte, defienden que el mundo funerario reproduce de alguna manera y con determinados filtros ideológicos el mundo de los vivos. De modo que en la elección que se hace del papel desempeñado en vida por el difunto,

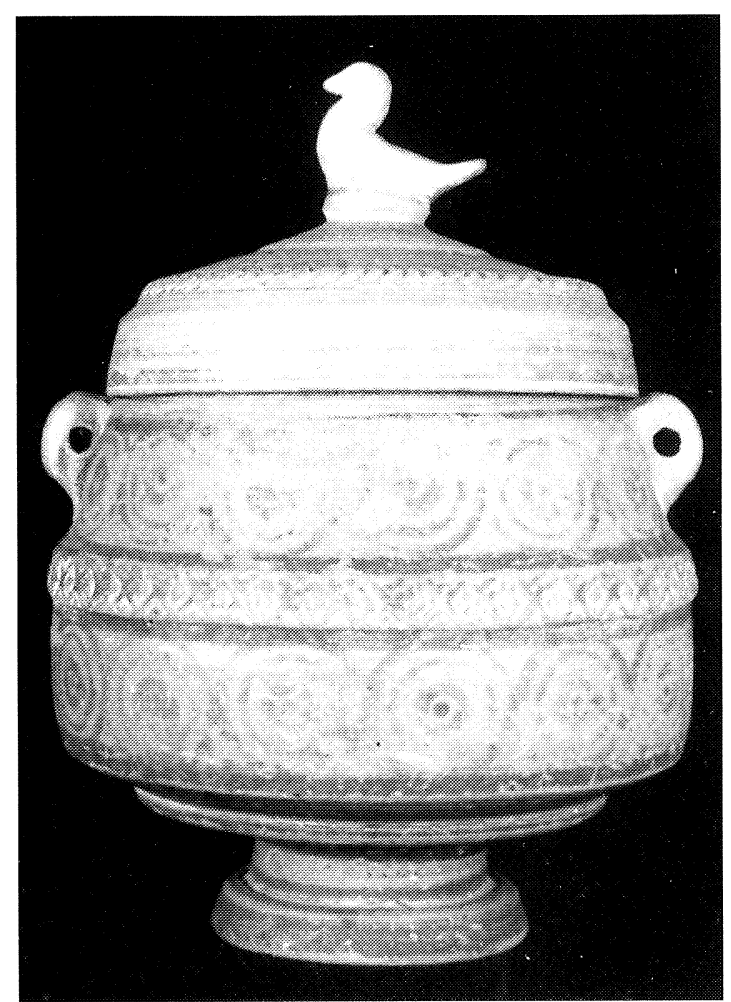

Fig. 10.-Ejemplar $n^{\circ} 1$ de Toya. Museo Arqueológico Nacional.

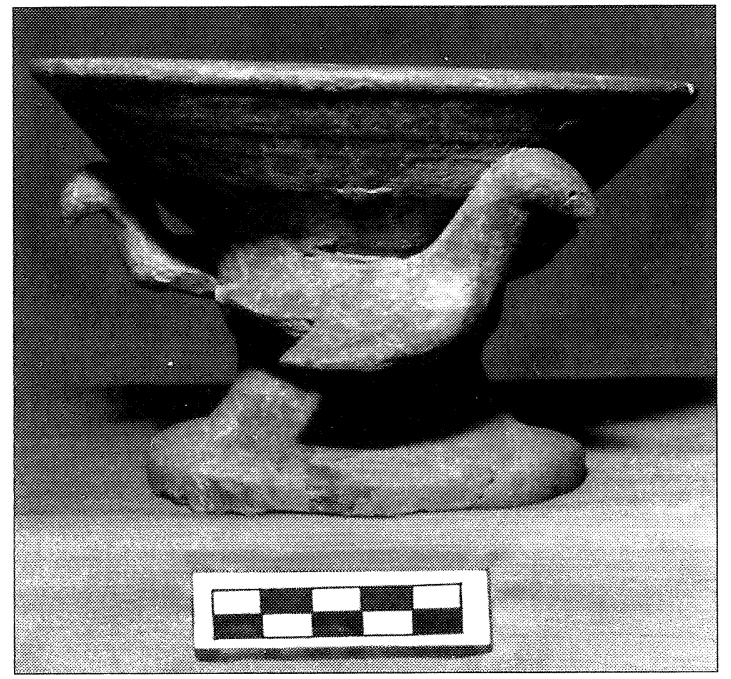

Fig. 11.-Copa de Alhonoz. Museo Arqueológico de Sevilla.

reflejada en el continente y contenido de la tumba, influyen distintos intereses del grupo social al que pertenece (Chapa, Pereira, Madrigal y Mayoral, 1998: 136). En el caso de los ejemplares estudiados, su contexto y características antes analizadas nos están indicando que su propietaria desempeñó un papel importante en el seno de la comunidad ibérica que vivió en Toya: el de sacerdotisa de una divinidad femenina.

La existencia y características del sacerdocio en el mundo ibérico es uno de los aspectos menos conocidos de la religión ibérica y que recientemente ha merecido un interesante trabajo por parte de Chapa y Madrigal (1997), en el que señalan que la existencia de un cuerpo sacerdotal se podría considerar a partir del siglo $v$ a.d.C. La aparición del sacerdocio en los pueblos ibéricos habría que insertarla en el marco de la expansión y urbanización de la sociedad ibérica, en el que la residencia de los jerarcas y el lugar de culto se distancian (Ruiz y Molinos, 1993) en un proceso cuyos paralelos más claros estarían en el mundo itálico (Torelli, 1996: 173). En el modelo que se propone existiría un personal especializado y un protagonismo en el ceremonial reservado al responsable político. Siguiendo este modelo, en el culto a las divinidades femeninas, algunos de cuyos símbolos son asimilados por las comunidades ibéricas, es más que probable que las mujeres de status más elevado tuvieran un importante papel como integrantes de un sacerdocio femenino, del mismo modo que debieron ejercer un importante papel en el plano político de sus comunidades, siendo el caso de la Dama de Baza paradigmático de la confluencia de estos dos roles (Pereira, 1989: 491). 
Según la propuesta de Chapa y Madrigal, entre los distintos elementos que con carácter no excluyente se podrían considerar como marcadores de dicho rango sacerdotal estarían:

Un status social elevado.

Iconografía específica en lo relativo al arreglo personal.

Atuendo y asociación con símbolos divinos.

Posible ausencia de armas.

Objetos implicados en prácticas rituales ligadas al culto.

Los ejemplares de Toya corresponderían al último caso de los señalados como marcadores del rango sacerdotal, no sólo por sus peculiaridades morfológicas soporte de una simbología relacionada con el culto de una divinidad femenina, sino por su funcionalidad funeraria como marcador del rol que le reconoce la sociedad a su propietaria.

¿Dónde ejercía la función sacerdotal la propietaria de los recipientes de Toya? Algunos autores consideran que, con la aparición de nuevos espacios donde se refleja el poder a partir de la segunda mitad del siglo v a.d.C., el área ibérica se subdivide en dos amplios territorios: el oriental donde predominan los templos urbanos, las cuevas y los lugares sagrados (Bonet y Mata, 1997: 117) y, en la zona meridional, los santuarios (Ruiz y Molinos, 1993: 249; Santos, 1996). Esta propuesta es matizada por otros investigadores, que distinguen en los santuarios urbanos del mundo ibérico un grupo que por sus características se pueden considerar como templos urbanos y un segundo grupo integrados en estructuras domésticas, también denominados «santuarios dinásticos», que aparecen en la Alta Andalucía y Levante con penetraciones en el Nordeste (Moneo, 1995: 246-248).

Los santuarios dinásticos aparecen por lo general integrados en una vivienda o una estructura no diferenciable de un espacio doméstico, si bien presentarían dimensiones o un carácter relevante dentro de la urbanística del oppidum. Este tipo de santuarios, aunque carece de un patrón constructivo uniforme, contaría con un patio de entrada y varios compartimentos cubiertos o no según los casos y las actividades a celebrar como los sacrificios, depósitos de ofrendas, etc. (Moneo, 1995: 247). En este tipo de santuarios la divinidad tendría relación con el grupo dirigente, ya que los sacerdotes procederían de las familias de alto estatus, con la posibilidad de que algunas de ellas lo ejercieran con carácter hereditario (Chapa y Madrigal, 1997).

Así pues, aunque la zona de hábitat de Toya no ha sido todavía explorada arqueológicamente y los restos de su necrópolis presentan problemas de contextualización, no cabe ninguna duda de la importancia que tuvo este oppidum por el control del estratégico territorio que domina la confluencia de los ríos Guadalquivir y Guadiana Menor. Es por lo tanto perfectamente posible la existencia entre sus estructuras de habitación de un «santuario dinástico», cuyo paralelo más directo en el Valle del Guadalquivir lo tendríamos en Alhonoz (López Palomo, 1981), en el que los recipientes que hemos estudiado fueron utilizados en las ceremonias de culto, para finalmente acompañar a su propietaria en su última morada como signo de su actividad sacerdotal.

\section{BIBLIOGRAFÍA}

Almagro Gorbea, M. (1974): Los asadores de Bronce del Suroeste Peninsular. Revista de Archivos, Bibliotecas y Museos. Vol. LXXVII. 1, pp. 351-395.

ID. (1977): El Bronce Final y el Periodo Orientalizante en Extremadura. Biblioteca Prehistórica Hispana. Vol. XIV. Madrid.

Almagro Gorbea, M.J. (1980): Corpus de las terracotas de Ibiza. Biblioteca Prehistórica Hispana. Vol. XVII. Madrid.

Amandry, P. (1991): L'Antre Corcyrien. Guide de Delphes. Le Musée, pp. 241-261.

Aranegui, C. (1992): La cerámica ibérica. Cuadernos de Arte Español. Edit. Historia 16. Madrid.

Arribas, A. (1965): Los Iberos. Edit. Ayma. Barcelona.

BeIrÂo, C.M. et alii. (1985): Depósito votivo de Garvâo. O Arqueólogo Português. Serie IV, 3, pp. 45-136.

Blanco, A. (1963): Tarros de cerámica andaluza. Oretania. $\mathrm{N}^{\mathrm{o}} \mathrm{s}$ 14-15.

Blánquez, J. (1995): El poblado ibérico de la Quéjola (San Pedro, Albacete). En El mundo ibérico: Una nueva imagen en los albores del año 2.000. Junta de Comunidades de Castilla-La Mancha, pp. 193-200.

BLÁzQueZ, J.M. (1955-56): Interpretaciones de la pátera de Tivissa. Ampurias. Vol. XVII-XVIII, pp. 111-139.

ID. (1957): Aportaciones al estudio de las religiones primitivas de España. Archivo Español de Arqueología. Vol. XXX, nº 95, pp. 18 y ss.

ID. (1975): Tartessos y el origen de la colonización fenicia en Occidente. Salamanca.

ID. (1983): Primitivas religiones ibéricas. II. Religiones prerromanas. Ediciones Cristiandad. Madrid. 
Boardman, J. (1978). Greek Sculpture. The Archaic Period. London.

Bonet, H. (1995): El Tossal de Sant Miquel de Llíria. La antigua Edeta y su territorio. Servicio de Investigación Prehistórica. Diputación de Valencia.

Bonet, H. y Mata, C. (1997): Lugares de culto edetanos. Propuesta de definición. Quaderns de Prehistória i Arqueologia de Castelló. Vol. 18, pp. 115-146.

Cabré, J. (1925): Arquitectura Hispánica. El sepulcro de Toya. Archivo Español de Arte y Arqueología. Vol. I, pp. 73-101.

CABRÉ, J. y Motos, F. (1920): La necrópolis ibérica de Tutugi (Galera, provincia de Granada). Memoria de la J.S.E.A. $n^{\circ}$. 25. 1918. Madrid.

CARdenete, R. et alii (1991): Excavaciones arqueológicas de urgencia en el solar de la calle Costanilla Torre del Oro s./n. Carmona. Anuario Arqueológico de Andalucía. 1989. Vol. III, pp. 563-578.

Conde, M.J. (1992): Colección Arqueológica, Duran-Vall-Llosera. Barcelona.

Cuadrado, E. (1987): La necrópolis ibérica de El Cigarralejo (Mula, Murcia). Biblioteca Prehistórica Hispana. Vol. XXIII. Madrid.

Chapa, T. y Pereira, J. (1991): El oro como elemento de prestigio social en época ibérica. Archivo Español de Arqueología. Vol. 64, pp. 23-35.

Chapa, T. y Madrigal, A. (1997): El sacerdocio en época ibérica. SPAL. Vol. 6, pp. 187-203.

Chapa, T.; Pereira, J.; Madrigal, A. y Mayoral, V. (1998): La necrópolis ibérica de Los Castellones de Céal (Hinojares, Jaén). Junta de Andalucía, Universidad de Jaén. Sevilla.

Escacena, J.L. (1986): Cerámicas a torno pintadas andaluzas de la $2^{a}$ Edad del Hierro. Tesis Doctoral. Universidad de Sevilla.

FERnÁNDEZ Gómez, F. (1992-1993): Un asador excepcional y un excepcional conjunto de asadores del Bajo Guadalquivir. Tabona. Vol. VII-II, pp. 465-480.

Fernández Chicarro, C. (1955): Noticiario Arqueológico de Andalucía. Archivo Español de Arqueología. Vol. XXVIII, pp. 322-341.

ID. (1956): Prospecciones arqueológicas en los términos de Hinojares y la Guardia. Boletín del Instituto de Estudios Giennenses. Vol. III. n 7, pp. 101-117.

Fernández-Miranda, M. y Olmos, R. (1986): Las ruedas de Toya y el origen del carro en la Península Ibérica. Ministerio de Cultura. Madrid.

García y Bellido, A. (1947): Ars Hispaniae. Barcelona.

ID. (1976): Arte Ibérico. En Historia de España di- rigida por Menéndez Pidal. Vol. I-3. Espasa-Calpe. Madrid.

ID. (1980): Arte Ibérico en España. Madrid.

González Prats, A. (1976-78): El tesorillo de tipo orientalizante de la Sierra de Crevillente. Simposio Internacional: Los orígenes del mundo ibérico. Ampurias. Vol. 38-40, pp. 349-360.

Griñó, B. (1992): Imagen de la mujer en el mundo ibérico. En La sociedad ibérica a través de la imagen. Ministerio de Cultura. Madrid, pp. $194-$ 205.

Iniesta, A.; Page, V. y García Cano, J. (1987): $E x$ cavaciones arqueológicas en Coimbra del Barranco Ancho (Jumilla). La sepultura 70 de la necrópolis del poblado. Murcia.

López Palomo, L.A. (1979): La cultura ibérica del Valle Medio del Genil. Caja de Ahorros de Córdoba.

ID. (1981): Alhonoz. Excavaciones de 1973 a 1978. Noticiario Arqueológico Hispánico. No 11 . Ministerio de Cultura, pp. 33-187.

ID. (1982): El poblado de Alhonoz (Herrera, Sevilla). Homenaje a Conchita Fernández Chicarro. Ministerio de Cultura. Madrid.

Llobregat, E. (1972): Contestania Ibérica. Alicante.

Madrigal, A. (1997): El ajuar de la cámara funeraria ibérica de Toya (Peal de Becerro, Jaén). Trabajos de Prehistoria. Vol. 54, n 1 , pp. $167-$ 181.

MaLPESA, E. (1993): La «sacerdotisa del Sol» y «el collar sideral»: La tumba 53 de Clares (Guadalajara). Boletín del Museo Arqueológico Nacional. Tomo XI, $\mathrm{n}^{\circ}$ s 1 y 2, pp.17-24.

Maluquer de Motes, J. (1987): La necrópolis paleoibérica de Mianes en Santa Bárbara (Tarragona). P.I.P. Vol. IX. Barcelona.

Martínez Santaolalla, J.M. (1946): Esquema Paletnológico de la Península Hispánica. Madrid.

Mergelina, C. de (1944): Tugia. Reseña de unos trabajos. Boletín del Seminario de Estudios de Arte y Arqueología. Vol. X, pp. 13-32.

Moneo, M.T. (1995): Santuarios urbanos en el mundo ibérico. Complutum. N ${ }^{\circ}$ 6, pp. 245-255.

Neumaier, J. (1996): Colgantes zoomorfos de las costas valenciana y catalana. Cuadernos de Prehistoria y Arqueología Castellonense. $\mathrm{N}^{\mathrm{a}}$ 17, pp. 255-261.

Olmos, R. (1985): Nuevos enfoques para el estudio de la cerámica y los bronces griegos de España. Una primera aproximación al problema de la helenización. Monografies Emporitanes. Vol. VII, pp. 7-18.

ID. (1989): Original elements and Mediterranean sti- 
muli in Iberian pottery: the case of Elche. Mediterranean Archaeology. Vol. 2, pp. 101-109.

ID. (1991): Nuevos enfoques y propuesta de lectura en el estudio de la iconografía ibérica. En Arqueología. Nuevas tendencias. C.S.I.C. Madrid.

ID. (1992): El surgimiento de la imagen en la sociedad ibérica. En La sociedad ibérica a través de la imagen. Ministerio de Cultura, pp. 8-32.

Olmos, R. y FernÁndeZ-Miranda, M. (1987): El timiaterio de Albacete. Archivo Español de Arqueología. Vol. 60, pp. 221-229.

Olmos, R. et alii (1992): Catálogo. En La sociedad ibérica a través de la imagen. Ministerio de Cultura, pp. 33-167.

Page, V. (1984): Imitaciones de influjo griego en la cerámica ibérica de Valencia, Alicante y Murcia. Iberia Graeca. Serie Arqueológica. Nº 1. Madrid.

Pallottino, M. (1955): Etruskische Kunst.

Pereira, J. (1979): La cerámica ibérica procedente de Toya (Peal de Becerro, Jaén) en el Museo Arqueológico Nacional. Trabajos de Prehistoria. Vol. 36, pp. 289-347.

ID. (1987 a): Necrópolis ibéricas de la Alta Andalucía. En Iberos. Actas de las I Jornadas sobre el Mundo Ibérico (Jaén 1985), pp. 257-272.

ID. (1987 b): La cerámica pintada a torno en Andalucía. Siglos vi al III. Cuenca del Guadalquivir. Tesis Doctoral. Universidad Complutense. Madrid.

ID. (1988): La cerámica ibérica de la Cuenca del Guadalquivir. I Propuesta de clasificación. Trabajos de Prehistoria. Vol. 45, pp. 143-173.

ID. (1989): Necrópolis Íbéricas andaluzas. Nuevas perspectivas en su valoración y estudio. En TARTESSOS. Arqueología Protohistórica del Bajo Guadalquivir. Edit. Ausa. Sabadell, pp. 477-494.

Pereira, J. y Chapa, T. (1991): Historia de la investigación de las necrópolis ibéricas de la Alta Andalucía: El área del Guadiana Menor. En Congreso Internacional: Historiografía de la Arqueología y de la Historia Antigua en España (Siglos XVIII-XX) (Madrid 1988). Ministerio de Cultura.

Pereira, J. y Sánchez, C. (1985): Imitaciones ibéri- cas de vasos áticos en Andalucía. Monografies Emporitanes. Vol. VII, pp. 87-100.

Pericot, L. (1934): Épocas Primitiva y Romana. Historia de España. Tomo I. Instituto Gallach. Barcelona.

ID. (1979): La cerámica ibérica. Edit. Polígrafa. Barcelona.

Prados, L. (1992): Exvotos ibéricos de bronce del Museo Arqueológico Nacional. Ministerio de Cultura. Madrid.

ID. (1996): Imagen, religión y sociedad en la toréutica ibérica. En Olmos, R. (Ed.) Al otro lado del espejo. Aproximación a la imagen ibérica. Colección Lynx. La Arqueología de la mirada. Vol. 1. Madrid, pp. 131-144.

Presedo, F. (1973): La Dama de Baza. Trabajos de Prehistoria. Vol. 30, pp. 151-216.

Rafel i Fontanals, N. (1997): Colgantes de bronce paleoibéricos en el N.E. de la Península Ibérica. Algunas reflexiones sobre las relaciones mediterráneas. Pyrenae. $\mathrm{N}^{\circ}$ 28, pp.99-117.

RAGA, M. (1994): Los materiales del poblado ibérico de la Covalta (Albaida, Valencia). Tesis de Licenciatura. Universidad de Valencia.

Ruiz, A. y Molinos, M. (1993): Los Iberos. Análisis arqueológico de un proceso histórico. Edit. Crítica. Barcelona.

SÁNCHEZ, C. (1991): El comercio de productos griegos en la Andalucía Oriental. Siglos v-VI a.d.C. Tesis Doctoral. Universidad Complutense. Madrid.

Santos Velasco, J.A. (1996) Sociedad ibérica y cultura aristocrática a través de la imagen. En OLmos, R. (Ed.). Al otro lado del espejo. Aproximación a la imagen ibérica. Colección Lynx. La Arqueología de la mirada. Vol. 1. Madrid, pp. 115-130.

Santos, M. (1998): Catálogo. En Cabrera Bonet, P. y Sánchez Fernández, C. (eds.), Los griegos en España. Tras las huellas de Heracles. Ministerio de Cultura.

Tarradell, M. (1968): Arte Ibérico. Barcelona

Torelli, M. (1996): Historia de los Etruscos. Edit. Crítica. Barcelona.

Uberti, M.L. (1975): Le terracotte. Anécdota Tharrhica. Roma, pp. 17-50. 